\title{
Caracterización molecular de dos brotes de distemper canino en animales de vida silvestre en Costa Rica
}

\author{
Martha Piche ${ }^{1} 凶$, Alejandro Alfaro ${ }^{2}$, Mauricio Jiménez-Soto ${ }^{3}$, Pablo Murcia $^{4}$, Carlos Jiménez $^{1}$ \\ 1 Lab. de Virología, PIET, Escuela de Medicina Veterinaria, Universidad Nacional \\ 2 Lab. de Patología, Escuela de Medicina Veterinaria, Universidad Nacional \\ 3 Hospital de Especies Menores y Silvestres, Universidad Nacional \\ 4 Centre for Virus Research, MRC-University of Glasgow, Scotland
}

El virus del distemper canino (CDV), es el causante de una importante enfermedad infecciosa que afecta perros, cánidos de vida silvestre y otros carnívoros. Es altamente patógeno, pertenece al género Morbillivirus, familia Paramyxoviridae; posee un ARN de polaridad negativa que codifica para seis proteínas mayores. La hemaglutinina $(\mathrm{H})$ y la proteína de fusión $(\mathrm{F})$ son las responsables de la unión y fusión con la célula. El gen $\mathrm{H}$ tiene la mayor variabilidad en todo el genoma, este gen se utiliza para clasificar las diferentes cepas virales. El virus causa problemas respiratorios, gastrointestinales y neurológicos en caninos de diferentes edades. En los últimos años se ha reportado un aumento de los casos de CDV en animales tanto de vida silvestre, así como en animales domésticos con y sin esquema completo de vacunación.

El objetivo de este estudio fue analizar mediante la amplificación y secuenciación del gen $\mathrm{H}$ de CDV dos brotes de distemper canino reportados en vida silvestre y compararlos con secuencias de animales domésticos. El primer brote se presentó en la zona de Escazú en pizotes (Nasua narica) mientras que el segundo se localizó en la zona de Monteverde en mapaches (Procyon lotor). En ambos casos los animales presentaban sintomatología nerviosa y conjuntivitis severa. Se realizó el estudio post mortem completo de los animales, todos presentaban una severa conjuntivitis y nasofaringitis mucopurulenta, severa neumonía intersticial difusa y encefalitis no supurativa. En ambos brotes se procesó material del sistema nervioso central para el diagnóstico virológico. A estas muestras se les realizó una primera reacción en cadena de la polimerasa (PCR) que amplifica parte de la nucleocápside, esta prueba se utilizó para determinar que las muestras eran positivas a CDV. A once muestras positivas se les amplificó el gen $\mathrm{H}$ en su totalidad. Mediante un análisis filogenético, que incluyó también cuatro secuencias del gen $\mathrm{H}$ obtenidas de casos clínicos de CDV en perros nacionales, se determinó que las muestras pertenecientes al brote de Escazú se relacionan con cepas de animales silvestres de Norteamérica, en tanto que las cepas de Monteverde y las cuatro cepas de perros domésticos, son similares a cepas colombianas reportadas en el año 2014 como un clúster diferente al resto de cepas suramericanas, donde también se clasifican las cepas de animales domésticos. Se concluye que los casos de distemper en dos especies silvestres de nuestro país son causados por cepas de CDV similares a las descritas en vida silvestre de Norteamérica y por cepas similares descritas en Colombia que se originan de perros domésticos.

\ Autor para correspondencia Martha Piche: mmpo88@gmail.com 